\title{
Gender, Uyghur Identity, and the Story of Nuzugum
}

\section{KARA ABRAMSON}

This article examines the relationship between gender and Uyghur identity through the story of Nuzugum, the allegory of a Kashgar woman who kills an enemy outsider she is forced to marry rather than yield her chastity and bear his children. Tracing the story from its nineteenth-century roots to literary, artistic, and political incarnations in recent decades, the article argues that the story's prominence in the canon of Uyghur literature and its eponymous protagonist's place among Uyghur national heroes highlights the integral but overlooked role of gender in the construction of modern Uyghur identity. The resiliency of the story's gendered themes also underscores gender's importance in contemporary Uyghur political advocacy, especially advocacy about the transfer of Uyghur women to factories in China's coastal cities, an issue connected to the July 2009 protests and riots in the Xinjiang Uyghur Autonomous Region.

W HETHER THROUGH THE LENS of ethnicity, nationalism, or the political categorizations of the Chinese and Soviet states, studies on the formation of Uyghur group identity are well represented, if not disproportionately so, in the field of Uyghur studies in the West (e.g., Bovingdon 2010; Bovingdon with Tursun 2004; Brophy 2005a, 2011; Gladney 1990; Roberts 2003, 2009; Rudelson 1997). Gender's role in defining this identity, however, remains largely overlooked. ${ }^{1}$ As a result, contemporary understandings of Uyghur collective consciousness fail to fully appreciate a key force that not only etched out group

\footnotetext{
Kara Abramson (abramsonkara@yahoo.com) is Visiting Fellow at the Institute for Advanced Studies on Asia at the University of Tokyo.

${ }^{1}$ Cornerstone works, noted above, concerned with the emergence and historical trajectory of Uyghur collective consciousness, and national consciousness in particular, have given little attention to gender issues. A limited number of other works, however, have either explicitly or implicitly addressed gender's role in the construction of Uyghur group identity. Brophy's (2005b) examination of forced marriage in Uyghur literature, including the Nuzugum tale, observes the importance of images of women in nationalist projects and highlights the role of Uyghur literary heroines in the context of gender roles forced into disarray by outside aggression. Eli's (2006) dissertation addresses gender and ethnicity among women in Kashgar and emphasizes their "cultural and symbolic values in ethnic identity construction. ..." (211). Bellér-Hann (2008) discusses gender relations and marriage in nineteenth- and early twentieth-century Xinjiang. Caprioni (2008) looks at modern gender issues broadly, with attention both to labor transfers involving Uyghur women and Rebiya Kadeer's role as a Uyghur leader. Dautcher (2009) examines masculine identity within one community in Ghulja in the 1990s, though in general does not link this focus to an examination of the role of gender in the construction of broader Uyghur group identity.
} 
boundaries and informed nationalist movements in the Uyghur past but also continues to shape notions of Uyghur identity in the present.

This article examines one set of crossing points between gender and Uyghur identity through the story of Nuzugum, the allegory of a Kashgar woman who kills an enemy outsider she is forced to marry rather than yield her chastity and bear his children. Tracing the tale from its literary and folk roots in the nineteenth century up to selected literary, artistic, and political incarnations of the story in recent decades, this article highlights the importance of Nuzugum as a window into at least three facets of gender and Uyghur identity. First, the story of Nuzugum as rooted in nineteenth-century Xinjiang helps support recent scholarship on Uyghur identity that dates the presence of a collective trans-oasis group consciousness-bounded in part by patterns in marriage and procreation-to eras predating Soviet- and Chinese-promoted definitions of Uyghur nationhood. ${ }^{2}$ Second, an examination of the story's position in the canon of Uyghur literature, the endurance of its themes in later literary and artistic works, and its protagonist's place in the constructed pantheon of Uyghur national heroes highlights the defining role of gender in the development of Uyghur national identity in the twentieth century. Finally, the resiliency of the story's gendered themes underscores the role of gender as an influence on contemporary Uyghur political advocacy and a defining component of communal consciousness even as the nature of Uyghur group identity continues to change.

\section{Gender, Identity, AND Nation}

Among the range of cultural, political, and social forces defining communal identities, feminist scholarship has stressed the socially constructed category of gender-and women's roles in particular-as an oft-overlooked but central component of group identity. Looking specifically at ethnic and national groupings, scholars have described a range of intersections with gendered roles, including men as the defenders of the collectivity and dominant voices in its explicit imaginings and women as biological and symbolic reproducers of ethnic groups and nations, "border guards" of their boundaries, conveyers of cultural mores and traditions, embodiments of group sanctity, markers of the difference between collectivities, and participants in ethnic or national struggles (e.g., Mayer 2000; Ranchod-Nilsson and Tétreault 2000; Yuval-Davis 1997, 23, citing Armstrong 1982; Yuval-Davis and Anthias 1989). ${ }^{3}$ As nationalism in particular has come to

\footnotetext{
${ }^{2}$ See Newby (2007, 15-16), Roberts (2009, 361-64), and Brophy (2005a, 164-65) for critical examinations of scholarship that pins the emergence of a coherent communal identity to state-imposed twentieth-century political projects and see their works generally for discussions of group identity both predating and extending into the twentieth century.

${ }^{3}$ The examples above draw in particular from Yuval-Davis and Anthias's (1989) five-part framework for examining women's roles in conceptions of ethnicity and nation.
} 
the fore as an expression of communal identity and aspirations, feminist scholarship has emphasized that the actual manifestations of nationalism-from the gendered stories that feed national narratives to the gendered hatred that promotes rape as a weapon to dilute the nations of enemies — spotlight gender as an engine that propels the nation.

In the field of gender and Uyghur identity, the story of Nuzugum covers limited but rich terrain. In various renditions of the tale at the hands of male authors, Nuzugum is at once a reproducer of communal and national boundaries, a symbol of her people's purity, a model of communal values, and a warrior in national struggles. She is not alone in embodying these sentiments. As gender has informed constructions of Uyghur identity in both the past and present, symbolic images of women have offered a powerful and malleable form to define the collectivity, and Nuzugum is one of multiple suffering heroines in Uyghur literature whose struggles against forced marriage carry both literary and political traction. ${ }^{4}$ As a particularly resilient narrative within this genre-which emerged locally atop a tradition of classicized love tales with Iranian and Arabic roots (Brophy 2005b, 57-58) — the story of Nuzugum provides an effective frame for highlighting themes of gender and Uyghur identity. At the same time, the existence of the broader literary genre reinforces the relevance and interconnectivity of these themes.

Nuzugum is especially significant as a trope of nationalism, which came to assume a hegemonic position in articulations of Uyghur group identity in the twentieth century. Current Uyghur political advocacy in diaspora, even at the helm of female leader Rebiya Kadeer, has continued within this framework of androcentric nationalism and replicates its norms, as underscored by Rebiya Kadeer's own promotion of gendered ideals as the "mother of Uyghurs" (e.g., Rafto Foundation for Human Rights 2010) and advocacy activities that reproduce gendered anxieties over the purity of Uyghur women.

The persistence of Uyghur nationalism is unsurprising given the Uyghurs' political history and recent events in the People's Republic of China (PRC). Against a backdrop of outside conquests, failed attempts at enduring independent polities, and unfulfilled grants of "regional autonomy" from the PRC, nationalism offers the vision of an eternal Uyghur homeland and the promise of self-determination to subvert outside claims to the region. At the same time, the range of forces affecting current Uyghur identity-especially for Uyghurs living under a seventh decade of PRC rule-cautions against collapsing all Uyghur political activity to nationalist sentiments pegged to aspirations for an independent state. The protests and riots in the Xinjiang Uyghur Autonomous Region in July 2009, sometimes mischaracterized in the West exclusively as a "riot" or "uprising" with implied separatist underpinnings, began as PRC-style

\footnotetext{
${ }^{4}$ See Brophy (2005b) for a discussion of other works in this genre.
} 
petitioning by young Uyghurs for redress against perceived state injustices. The civilian violence that followed illustrated deep ethnic tensions in the region, but not in the form of organized national resistance to PRC control. As new economic and educational policies from the PRC may reshape aspects of Uyghur identity inside China, while the conservative impulses of the international status quo affect how Uyghurs present their claims in diaspora, Uyghurs in the twenty-first century may come to articulate new notions of identity that dislodge the dominant position of Uyghur nationalist discourse. Yet even as the events of July 2009 already suggest more diverse conceptions of Uyghur identity beyond a monolithic Uyghur nationalism, the prominence of an array of gendered concerns during these events, discussed below, indicates gender's continued importance in defining Uyghur identity.

This article first examines multiple versions of the Nuzugum story and then returns to the question of gender and Uyghur identity to examine how the story's protagonist became a hero to her people, a muse of Uyghur nationalism, and a symbol of the anxieties underlying current Uyghur political advocacy regarding Uyghur women's participation in Chinese government-led labor transfer programs.

\section{NuZugum in Word AND Song}

\section{Bilal Nazim's Nuzugum}

Molla Bilal binni Molla Yüsüp (known as Bilal Nazim, approx. 1825-1900), the nineteenth-century Ghulja-born poet, satirist, and historical chronicler, provides the first full written narrative of what has now become a cornerstone of Uyghur literature: the story of Nuzugum. Structured as a short dastan, a literary form defined by passages of prose coupled with sets of verse (Light 1998, 460-61, 468), Bilal Nazim's 1882 story of Nuzugum chronicles the life of a woman said to have participated in the Khoqand-based Jahangir Khoja's 1826 attack in Kashgar against the Qing and whose travails were immortalized in folk tales told throughout the Ili valley where she was later exiled. ${ }^{5}$ Bilal Nazim's own text survives through a Russian translation published by the scholar Nikolai Pantusov in Kazan in 1909 and in a compilation of "literature of the Uyghur people," published in Moscow in 1925, which represented an early and contested endeavor to establish a unified "Uyghur" national literature (Brophy 2011, 296-97). In

\footnotetext{
${ }^{5}$ Some secondary-source works treat Nuzugum as a historical figure, and some have cited the folk songs attributed to her to identify her as representative of nineteenth-century Uyghur writers (see, e.g., Kazakhstan SSR Academy of Sciences 1983, 96), but the works do not appear to draw on sources other than the nineteenth-century folk songs and Bilal Nazim's story. As cited in Brophy (2005b, 58), chronicler Musa Sayrami’s account of the region's history observes that those captured or exiled after the Jahangir attack later "made up the 'Nazugum' song," after which it was "disseminated among the people."
} 
addition, the journal Bulaq (Water Spring), based in Xinjiang, published a modern Uyghur-language edition of the story, nearly identical to the earlier texts, in 1981. ${ }^{6}$

The story of Nuzugum ends with the lesson that pure women obtain their due in heaven and begins with an account of the hardships that put the character of pure women to the test. Chinese (xitay) forces ${ }^{7}$ have just suppressed the Jahangir attack in Kashgar, killing the men and exiling the women to Ili, with orders to let Kalmaks - an apparent reference to descendants of Oirat Mongols who escaped Qing massacres of the Zunghar federation, which itself had subjected local populations in eastern Turkistan ${ }^{8}$ - take the women as their wives. A beautiful and learned young woman, known as "Nuzugum" ("my delicate one" $)^{9}$ has been given to a Kalmak along with her brother. Nuzugum's brother urges her to flee. "If you don't," he says, "the Kalmaks will have you. All the children born to you will be Kalmak, and you yourself will be like the wretched infidels" (Bilal Nazim [1882] 1981, 213). Nuzugum heeds his advice and flees into the wilderness, making her home among the reeds and singing out her sorrows. Learning of Nuzugum's flight, the great general of Köre sends out a band of Solons ${ }^{10}$ —a Tungusic group that served the Qing-to search for her. In one verse, Nuzugum sings: "If they set fire to the reeds, / Let me flee into the river. / I'll never be a wife / To the vile-hearted Solon" (216).

In the end, however, the Solons capture Nuzugum, and she eventually ends up in the hands of a Solon to take as his wife. In his joy, the Solon gets drunk, and Nuzugum uses this chance to slit his throat and kill him. She flees and is again captured but takes pride in having remained pure: "This bud of mine, given by God, / Was not destroyed by the infidel Solon. / Nuzuk was not made a wife / In the infidel Solon's home" (221).

Nuzugum predicts her death sentence but takes comfort in it, singing, "According to what the mullahs say, I'll be an exalted martyr" (223). The Qing

\footnotetext{
${ }^{6}$ Given the similarities between Pantusov's text and the modern Uyghur edition published in Bulaq, and because I can access the Bulaq version in the modern Uyghur rather than in translation, I have chosen to use the Bulaq version here as the basis for my discussion, but where there are discrepancies with the Russian text (on file in an unpublished English translation), I defer to the earlier Russian version. The edition published in 1925 is almost identical to the two other versions but is missing passages at the beginning and end of the story.

${ }^{7}$ Bilal Nazim [1882] 1909, 49. The troops are described as Manchu in the Bulaq version (Bilal Nazim [1882] 1981, 211), likely reflecting a necessary shift in the PRC context to position the narrative away from a perceived Uyghur struggle against the Chinese, as well as to avoid the word xitay, deemed within the PRC as a pejorative name for the Han.

${ }^{8}$ See Millward (2007, 88-89) and Perdue (2005, 292-99) for additional discussion of Kalmaks and the array of designations given to them. Millward notes that Islamic sources occasionally also applied the name to Manchus and eastern Mongols.

${ }^{9}$ Her name also has been rendered in various texts as "Nozugum" or "Nazugum" and occasionally as one of these three versions but using a "k" or "kaf/ke" in place of the "g" or "gap/ge." In addition, in various parts of the story, Nuzugum refers to herself as Nazuk, Nozuk, or Nuzuk.

${ }^{10}$ Janhunen $(1996,71)$ notes that the name "Solon" also has been applied to the Mongolic Dagurs.
} 
emperor indeed orders Nuzugum's death, and she is brought to the execution ground and decapitated. In a passage absent from later retellings of the story, some 200 Tungans (Chinese Muslims known today as the Hui, who alternately coexisted and contended with coreligionists inside eastern Turkistan) gather up Nuzugum's head and body and conduct religious rites. The story ends with a verse explaining that if women are pure like Nuzugum, they need not fear their oppressors and will find perfection in heaven. ${ }^{11}$

Bilal Nazim was the first chronicler to provide a full portrait of Nuzugum in prose and verse, but he was not the only nineteenth-century figure to set her story to paper. Based on material he collected in Ili in the 1860s, Turkologist Wilhelm Radloff (1886, 210-11) included a folk song about Nuzugum in his 1886 collection of folk tales and songs of the Taranchi, descendants of the inhabitants of oases in the Tarim basin taken to the Ili valley by Zunghars and later by the Qing. His Nuzugum is a young woman shackled by a wicked Chinese infidel (xitay kapir) and held far from home, threatening murder if he approaches her. In addition, in the same year that Bilal Nazim wrote his story, Pantusov collected folk songs from the Ili region that included a set of verses about Nuzugum, providing a short account of her separation from a beloved in Kashgar, as she is pursued by Chinese, Kalmaks, and Solons, and sentenced to die for unspecified crimes (Pantusov 1890, 7-8).

\section{Nuzugum Reimagined}

New ideas of collective identity in the early twentieth century brought new imaginings of Nuzugum. A transformed version of the story was created in the early $1920 \mathrm{~s}^{12}$ by Nezerghoja Abdusémetow, the Taranchi intellectual in Semirech'e (within present-day Kazakhstan), known by the pen name Uyghur Balisi (Child of the Uyghur), who played a prominent role in the promotion of a Uyghur national identity. ${ }^{13}$ Incorporating socialist modes to advocate for a Uyghur national identity —including use of the name Uyghur ${ }^{14}$ —Nezerghoja Abdusémetow portrays Nuzugum ${ }^{15}$ not as a woman who kills to keep her chastity but as a symbol of the need for his people to cast off superstition and oppression to unite and reclaim the strength of a Uyghur nation. His version of the story is thus an outlier among the works bearing her name, but also a strong illustration of the plasticity of the narrative to meet the political expediencies of different eras.

\footnotetext{
${ }^{11}$ The Bulaq version identifies the oppressors as the Manchus and the Pantusov text identifies them as Chinese (Bilal Nazim [1882] 1981, 225; [1882] 1909, 60). The passage is missing from the 1925 version.

${ }^{12}$ Roberts dates the text to 1921 and Mollawutow dates it to 1922 (Roberts 2009, 371; Mollawutow [1968] 2002a, 105).

${ }^{13}$ See, e.g., Roberts $(2003,2009)$ and Brophy $(2005 \mathrm{a}, 2005 \mathrm{~b}, 2011)$ for detailed discussions of Nezerghoja Abdusémetow.

${ }^{14}$ For a discussion of Nezerghoja Abdusémetow's use of the ethnonym, see Roberts (2009, 367-68) and Brophy (2005a, 170).

${ }^{15}$ Spelled in his story as "Nazugum."
} 
Nezerghoja Abdusémetow's story carries some of the same folk verses as Bilal Nazim's, and his eponymous heroine also chooses to flee rather than endure a captive relationship with an outsider, but, as a vehicle for the author's vision of Uyghur nationhood, a number of key details differ. We learn at the start of the story, for example, that Nuzugum is not a native of Kashgar but a young woman from Ghulja, a locality that would have carried more resonance with Nezerghoja Abdusémetow's immediate audience of Taranchis inside the Soviet Union who had recent roots in the Ili valley. At the same time, his Nuzugum makes reference to a "Uyghur people," serving as a mouthpiece for Nezerghoja Abdusémetow's aspirations for a larger Uyghur identity beyond one group. ${ }^{16}$

When the "Manchu-Chinese" (manjur-xitaylar) raid the area and take Uyghur youths captive, a Kalmak captures Nuzugum. The Kalmaks present Nuzugum to an official (daren) who, entranced by Nuzugum's beauty, ensconces her in a fancy home and treats her kindly. Nuzugum is without her freedom, however, and this theme is central to the story and to Nezerghoja Abdusémetow's depiction of her suffering. Nuzugum sings of her sorrows and pines for her family and her sweetheart Baqi. After Nuzugum manages to escape and reunite with Baqi, the two flee to a cave, where Nuzugum recites a long poem describing the greatness of the Uyghurs' history, serving as a vehicle for Nezerghoja Abdusémetow to educate his readers and call them to claim his vision of an illustrious and ancient Uyghur past. After soldiers catch Nuzugum and she is sentenced to death, she and others condemned to die stand before a crowd of onlookers and sing that the Uyghurs will soon be free. At the story's end, however, Nezerghoja Abdusémetow laments that Uyghurs have since failed to achieve liberation. He exhorts his readers not to forget Nuzugum and dedicates his story to Uyghur youth, urging them to rise up against oppression.

Politically incubated in this fashion by Nezerghoja Abdusémetow and nurtured by a core of developing Uyghur nationalism in Central Asia, Soviet Uyghur intellectuals recast the Nuzugum story on multiple occasions, including in 1930s and 1970 retellings (Brophy 2005b, 59, 60), and in a range of media including a 1950s opera (Kuzhamiarov 1958) and stage and musical adaptations (Mollawutow [1968] 2002, 105). More recent depictions reveal not only the story's traction in Central Asia but also its powerful resonance in diaspora communities and within Xinjiang. These portrayals, not exhaustive, include Uyghurlanguage collections of folk music (Hoshur 2006; Ömer 1981), a Mandarin translation of Uyghur folk verses (Abudukelimu and Jing 1981), contemporary poetry (Yasin 2004), a topic of study in a high school textbook (Hemraéw,

\footnotetext{
${ }^{16}$ While Nuzugum's new affiliation here appears to suggest a bias toward local identity that would weaken notions of Uyghur nationhood (an argument made by, e.g., Rudelson 1997), recent works on Taranchi intellectual history (Brophy 2005a, 2011; Roberts 2009) have stressed the existence of broader understandings of group identity that transcended local identities even while Taranchi voices were particularly strong in the emergence of Uyghur nationalism.
} 
Ershidinow, and Imirow 1993), short descriptions of the story on diaspora Web sites (Meshrep 2006; Uyghurbiz 2009; Wetinim 2009), film (Tilivaldi 2005, 84-88), a music video ("Nazugum" 2008), and a dramatic pageant of Uyghur national heroes at a diaspora gathering (Radio Free Asia 2008). Beyond this, Nuzugum has given her name to the site in Kazakhstan where she is believed to have concealed herself from her oppressors (Hoshur [1983] 2012, 359; Tilivaldi 2005, 84-88; Toxtamow 1988, 254-55), and appears to have served as inspiration for the name of a foundation (Amnesty International 2002) and beauty products presumably as pure as the name they bear ("Nuzugum" n.d.). This broad array of representations illustrates Nuzugum's elevation to a national icon who transcends strictly literary realms.

Three more recent versions of the Nuzugum story from Xinjiang or republished there also illustrate Nuzugum's continuing significance. These renditions return to Nuzugum's roots as a woman of nineteenth-century Kashgar and adhere to the contours of Bilal Nazim's narrative, but they also embellish the story with details informed by twentieth-century notions of a unified Uyghur national identity that claims Nuzugum as part of an unbroken historical narrative of the Uyghur nation. In the 1983 novella Nozugum, by the prolific Ghulja-born writer Memtimin Hoshur, overt expressions of nationalism are muted, staying within PRC dictates that confine interpretations of pre-1949 conflicts in Xinjiang to battles against ruling class oppressors rather than the struggles of a Uyghur nation (Bovingdon with Tursun 2004, 356). The novella refrains from ethnic designations, ${ }^{17}$ but the story's details allow for an alternate reading that fulfills the sentiments of a crystallized Uyghur nation that stands in opposition to outside oppression, from one generation to the next.

In Memtimin Hoshur's retelling, Nuzugum is a valiant soldier who joins the men to fight against Qing troops. After she is captured, her father sends a message urging her to stay true to her people and to her true love, Baqi. He explains, "Because she is a girl, preserving her chastity and purity is superior to all else" (Hoshur [1983] 2012, 316). The preservation of chastity, however, is not simply a woman's duty. In one scene, a local mullah otherwise willing to serve as a lackey of the Qing draws the line at conveying a Qing general's order that the families of Kashgar hand over their prettiest girls to the soldiers. Rather than bow to this demand, he attacks the general and ultimately kills himself.

As before, Nuzugum is sold off for marriage, kills her would-be husband on their wedding night — in this version, a Qing official_-and flees into the wilderness. She is ultimately captured and executed, but in the end, Nuzugum's beloved Baqi avenges her death. In a passage rich with reference to key events in Uyghur historical narratives, Baqi dies bravely in the uprisings of the 1860s,

\footnotetext{
${ }^{17}$ The exception is mention of the Manchu in verses drawn from the version of Bilal Nazim's text published in Xinjiang (Hoshur [1983] 2012, 363, 364).
} 
and the folk hero Sadir Palwan gives Baqi's sword to a young man to continue the fight.

Hüsiyin Tash's 2003 novella Women's Pride-Nuzugum, published in Xinjiang in a series on "historical figures" for younger readers, continues in the tradition of depicting Nuzugum's struggle as resistance against feudal oppression, while also situating it in a broader Uyghur national narrative that professes a centuries-long struggle for freedom. Hüsiyin Tash's Nuzugum is an outlaw from the story's beginning, stabbing a soldier as she defends a Uyghur girl against abduction. By the story's end, she has killed an official and numerous soldiers, in addition to the Solon with whom she is forced into marriage, but she proclaims she is innocent because seeking freedom is not a sin.

In Soviet Uyghur writer Turghan Toxtamow's novel Nazugum, originally published in the Kazakh SSR in 1988 and republished in Xinjiang in 2001, Nuzugum and Baqi_refigured as wife and husband_fight valiantly against the Manchu but are defeated. Much of the novel centers around Nuzugum's subsequent forced march to Ili. As Nuzugum comforts her companions on the arduous journey, her friends liken her courage to that of the "Fragrant Concubine," Iparxan, a legendary figure in both Chinese and Uyghur traditions said to be the Qianlong Emperor's concubine. ${ }^{18}$ Nuzugum elaborates on the story of this "heroine of the Uyghur people," describing her as a courageous fighter who kills the officials around her before killing herself and-in a line missing from the Xinjiang edition (Toxtamow 2001)_whose tomb beckons the people to a "struggle for national freedom" (Toxtamow 1988, 49). ${ }^{19}$

Once in Ili, Nuzugum is reunited with her brother but is sold off to a Kalmak. Before the two are separated, Nuzugum's brother, as in Bilal Nazim's version, urges her to flee, lest she bear Kalmak children. Nuzugum runs away, is caught, and eventually ends up in the home of a Solon, whom she kills as he forces himself on her. As in other versions of the story, Nuzugum is again captured and executed. In a postscript, Turghan Toxtamow describes the cave where Nuzugum hid herself after killing the Solon and explains that the site serves witness to Nuzugum's deeds, preserving her story from generation to generation.

\section{Nuzugum as Uyghur National Hero}

Bilal Nazim's 1882 story of Nuzugum predates a crystallized Uyghur national identity but nonetheless reflects an extant group consciousness that, like later

\footnotetext{
${ }^{18}$ See Millward (1994) for more information on the Iparxan story.

${ }^{19}$ Other than differences in orthography, the edition published in Xinjiang is almost identical to the original version, but a limited number of passages have been deleted or changed — as illustrated in the example above-in some cases apparently to avoid words or sentiments deemed politically sensitive.
} 
notions of Uyghur national identity, was etched out in part by gendered roles. Written in a time when Turkic Muslim authors wrote broad histories of their people and their land that transcended local oasis identities (Kim 2004, xiv, 73-74), this story of a heroine in 1820s Kashgar, as elaborated from oral literature five decades later by a Ghulja writer, reflected this project to capture a perceived common historical experience. Bilal Nazim transforms his Nuzugum from the roughly sketched protagonist of local folk tales to a fully fleshed-out heroine whose deeds bear significance for a larger collectivity facing continued repression. As the men in her life encounter defeat at foreign hands-described by Brophy $(2005 \mathrm{~b}, 62-63,64)$ as a dislocation of traditional gender rolesNuzugum assumes a central position in this struggle by giving her own life rather than yield her body to outside aggressors. These Kalmak and Solon men are dangerous, however, not simply as enemies threatening harm to her people but as non-Muslim outsiders whose acts of forced marriage threaten the very identity of the group. In an era when religious identity served as a potent, if at times fragile and ephemeral, unifying force both for Turkic Muslims and coreligionists inside eastern Turkistan (Kim 2004, 181), religion as an axis of identity in Bilal Nazim's Nuzugum is particularly salient in the story, as is the position of women in reproducing group boundaries informed partly by religious identity. At the same time, religion was not an exclusive marker of identity, and the range of affiliations in Bilal Nazim's story-including Kashgarliq (person from Kashgar), Muslim, infidel, Chinese, Kalmak, Solon, and Tungan-reflected multivaried and contextual expressions of identity. Religion took its place among a range of factors that were coalescing in the second half of the nineteenth century and would form the foundations of Uyghur nationalist projects in the twentieth.

Late twentieth-century Uyghur commentators rooted in a tradition of modern nationalism have projected a nationalist reading onto Bilal Nazim's nineteenth-century text, pinning the heroics of Bilal Nazim's Nuzugum not only to her chastity but also to the broader honor of her people and their related struggles. In doing so, Nuzugum comes to embody multiple gendered tropes of nationalism (and even pan-nationalism), symbolizing the purity of Uyghur women, the purity of her nation, and the boundaries of Uyghurness. Uyghur diaspora leader Erkin Alptekin, writing about Uyghur literature in a 1978 Turkish publication, explains, “The importance of [Bilal Nazim's story] is that [Nuzugum] is a strong nationalist and a Turkish Uyghur woman who is closely tied to her homeland and her nation" (Alptekin 1978, 71). A 1983 analysis from the Uyghur Studies Division of the Kazakhstan Academy of Social Sciences lauds Nuzugum for being a patriotic woman who recognizes that "her chastity is the chastity of her people" (Kazakhstan SSR Academy of Sciences 1983, 178). Writers also commend Bilal Nazim for his role in chronicling Nuzugum's story, similarly enshrining him as a mythologized figure whose actual motives and actions, like his subject, are put to the service of the Uyghur nation. Erkin Alptekin 
explains, "Bilal Nazim's love for his homeland and his nation and his interest in achieving independence for his homeland were identical to those of [Nuzugum]" (Alptekin 1978, 71). The editor of the 1981 edition of Bilal Nazim's "Nuzugum" applauds Bilal Nazim for "creating a typical image of a brave, freedomloving, patriotic, and heroic Uyghur girl" who "gave her all for the people's freedom and liberty" (Bilal Nazim [1882] 1981, 210).

Twentieth- and twenty-first-century versions of the Nuzugum story, from Nezerghoja Abdusémetow's short story to the later novellas, novel, and other renditions, illustrate the tale's endurance and elasticity to fulfill new visions of Uyghur identity. Nezerghoja Abdusémetow's story transforms the Nuzugum narrative to promote the ideas of socialism and nationalism animating his political aspirations and provides a platform for addressing a populace that, to his mind, had failed to embrace a common Uyghur identity. ${ }^{20}$ His Nuzugum represented a notion of Uyghurness that was, however, still finding its footing, and Nuzugum was at once a Ghuljiliq (person from Ghulja), a Taranchi, and a Uyghur, in a homeland described, at different points, as the Uyghur éli (Uyghur country) and Uyghuristan. ${ }^{21}$ In Memtimin Hoshur's work, Uyghur national identity is never made explicit, yet Nuzugum's roles as a symbol of and participant in her nation's struggles, an emblem of its purity, and an enduring hero within Uyghur historical consciousness is clear. Hüsiyin Tash's work continues this mode of balancing PRC-sanctioned versions of history with a narrative that positions Nuzugum's struggle as a broader fight for her nation. In Turghan Toxtamow's novel, first published outside of PRC constraints, Nuzugum is a fully formed symbol of Uyghur national identity, embodying multiple intersections of gender and nation as a symbolic reproducer of the Uyghur nation, a model of Uyghur womanhood, a symbol of her nation's purity, and a fighter in a Uyghur national struggle.

Other recent retellings of the Nuzugum story also explicitly use her as an emblem of a crystallized Uyghur national identity. A poem entitled "The Call of Nuzugum," by the now-imprisoned Kashgar writer Nurmemet Yasin (2004), describes a bed of reeds that "fiercely burns / And with it the hopes of a whole nation." ${ }^{, 2}$ A short entry on a diaspora Web site (Wetinim 2009) describes Nuzugum as a historical figure and "patriotic and heroic Uyghur girl" who "knows the shame of being a wife to a foreigner," kills a Solon, and flees. A posting titled "The Uyghur Girl Nuzugum" on another diaspora Web site (Meshrep 2006) provides a skeleton sketch of her as a beloved poet with "an

\footnotetext{
${ }^{20}$ See, e.g., Brophy $(2005 \mathrm{a}, 170)$ for more discussion of Nezerghoja Abdusémetow’s frustrations about the absence of a unified Uyghur identity.

${ }^{21}$ See Roberts $(2009,367-68,371)$ for a discussion of different ethnonyms used in Nezerghoja Abdusémetow's works and of how the continued use of the ethnonym Taranchi "suggested that the united Uyghur nation remained an ambiguous concept" (371).

${ }^{22}$ From the English translation.
} 
eternal place in the hearts of our people," extolling her for knowing that "ethnic pride, pure conscience, and chastity are superior to all else."

Additional examples further illustrate Nuzugum's place in a constructed pantheon of Uyghur heroes that claims roots well over a millennium and is an integral part of notions of contemporary Uyghur identity both in Xinjiang and in diaspora. In a 2008 holiday gathering of Uyghurs near Washington, D.C., that featured a performance by young men and women dressed up as the lions of Uyghur history, a woman wearing a simple Uyghur-style dress, warrior's headband, and long sword took up her place next to eleventh-century scholar Mehmud Kashgari, the legendary musician Amannisaxan (claimed as the sixteenth-century compiler of the Uyghur muqam musical suites), twentiethcentury nationalist poet Abduxalik Uyghur, and heroes of the East Turkistan Republic. ${ }^{23}$ In Kazakhstan, the cave where Nuzugum is said to have spent her last days bears a plaque noting Nuzugum's birth and death dates-thus enshrining her as a historical figure-and describing Nuzugum as a "hero of the Uyghur people who sacrificed her own life for the honor and freedom of the country" (Tilivaldi 2005, 84-88). In a 2010 speech for Women's History Month at the U.S. Department of State, Uyghur diaspora leader Rebiya Kadeer cited Nuzugum, "a participant in the Kashgar uprising of 1825-26," among women who embodied the "strong position of women in Uyghur life" (Radio Free Asia Unplugged 2010).

\section{Nuzugum and Modern Uyghur Poltitical Advocacy}

Concerns about identity, purity, and miscegenation extend beyond the story of Nuzugum and have taken a central position in contemporary Uyghur advocacy and grievances about a Chinese government policy of transferring the female "surplus labor force" in Xinjiang to factory jobs elsewhere in China. At the heart of the perceived injustice of the program — which PRC state media and government sources describe as a way to address unemployment, boost Mandarin skills, and, by some accounts, shed outdated traditions or promote "ideological" education (Congressional-Executive Commission on China [CECC] 2010, 21112) - are not only reports of exploitative labor practices and coercive means to gain participation but also fears that women in the programs will become prostitutes or marry Han men.

As a key concern of Uyghur advocacy, the issue of labor transfers has been the subject of a research paper by the Uyghur Human Rights Project (UHRP 2008), a topic of testimony by Uyghur leader Rebiya Kadeer before the U.S. Congress ("Tom Lantos Commission on Human Rights Hears Testimony on China's One Child Policy" 2009; UHRP 2007), and a key issue to promote for inclusion in

${ }^{23}$ I was a guest at the event. See also Radio Free Asia (2008). 
U.S. congressional resolutions on human rights abuses in Xinjiang (e.g., U.S. Senate Resolution 574). The 2008 report by the UHRP — a National Endowment for Democracy-funded human rights organization affiliated with the Uyghur American Association-enumerated a range of labor abuses in government-led programs to send Uyghur women to jobs elsewhere in China, including coercion and deception to gain participation, poor working conditions, and lost wages. Some of these abuses were later corroborated on a case-by-case basis by independent media (Cha 2009; Jacobs 2009) following a fight in Shaoguan, Guangdong province, in June 2009 involving Uyghurs in the labor transfer programs. At the same time, U.S. media outlets, government reports, and academic articles also have acknowledged the complex nature of the labor transfer programswhich also include Uyghur men, though apparently in fewer numbers, and take place in other parts of China (CECC 2009, 265; Millward 2009, 349) and have cited some participants who said they have taken part willingly and benefited from the programs (Cha 2009; Jacobs 2009; McLaughlin 2009).

Beyond the documentation of economic exploitation and labor violations, Uyghur advocates also have made broader and unconfirmed allegations of abuse, focusing in particular on gender and sexuality. Rebiya Kadeer testified before the U.S. Congress in 2007 that women in the labor programs were "forcibly transferred" and became "cheap slave labor and potential sex workers." Noting that a large number of Uyghurs conjecture that the program is aimed at having the women marry Han men, she said that they "see this as one of the most humiliating policies to date" (Reuters 2007). Enver Tohti (2010), Chair of the Uyghur U.K. Association, said at a London think tank meeting that Chinese authorities "have encouraged the girls [transferred to jobs elsewhere in China] to meet and marry local Chinese men. If they don't then they get sold to prostitution $[\mathrm{sic}]$ or punished." Even where marriage is not described as forced, it is still viewed as a threat to Uyghur women and to the general wellbeing and continuity of the Uyghur people. The agency of Uyghur women is thus subsumed to a strategy that blurs distinctions between force and free will for the sake of sustaining specific visions of the nation. Though Uyghur advocates have accused state authorities of disregarding young women's consent and pressuring them to participate in the labor transfer programs, consent in the context of marriage and sex work appears less relevant where it is perceived to challenge the integrity and sanctity of the nation.

Uyghurs inside China also have expressed broad concerns about the programs, centered around the perceived forced nature of female participation and the threats of intermarriage and sexual debasement. Though articulated outside a framework of diaspora nationalism, they replicate male claims over the female body for the sake of the collectivity, while also suggesting male anxieties about the communal implications of women's economic independence and mobility. A YouTube video from Xinjiang cites Uyghur men airing their grievances about what they described as the forced transfer of young Uyghur women 
to jobs elsewhere in China, with one man arguing that they would not have participated of their own accord ("Uyghur Farmers: Forced Labor, Forced Migration of Girls" 2008). A Kashgar resident cited in a Washington Post article said his sister was coerced into participating and added, "She is a girlaccording to our religion and culture, girls don't go to such distant places" (Cha 2009). A New York Times report noted families' concerns that the program diminished women's chances of marriage and cited one young man who said, "I would not marry such a girl because there's a chance she would not come back with her virginity" (Jacobs 2009). The now-imprisoned Uyghur journalist Gheyret Niyaz analyzed these concerns in an interview with Hong Kong media following the July 2009 protests and riots in Urumqi:

As for organizing Uyghurs to go out to work, in the eyes of nationalists, you can make jokes about whatever you want, but you better not joke about the women. The earliest groups of workers sent out to work were almost all 17- and 18-year-old girls, and at that time, some local village elders said, "Of these girls, 60 percent will become whores and 40 percent will be married off to Han." This generated huge disgust. As the government dealt with this issue, in the first place, it didn't do sufficient ideological work, and, in the second place, it didn't realize that such a little thing could have such a great effect. (Li 2009)

The perceived dangers of intermarriage are not new, as illustrated by phenomena including but not limited to the prominence of the story of Nuzugum for well over a century. As Uyghur nationalism found a platform in the second East Turkistan Republic in the 1940s, intermarriage was in that era, according to historian Linda Benson (1990, 165), a "perennial problem" and an "explosive" issue. The failure of the coalition government to impose a ban on marriages between Han men and Muslim women was a source of discontent $(114,164)$ that appeared to tap a reserve of anger and resentment over the issue that dated back generations. ${ }^{24}$ We may not know whether the typical marriage between a Han man and a Uyghur or Muslim woman reflected more or less free will on the woman's part than did a marriage between Uyghurs or MuslimsIldikó Bellér-Hann (2008, 83-84) notes that marriage to Han men brought certain socio-economic advantages to local Muslim women in nineteenth- and early twentieth-century Xinjiang-but the power of such marriages to inflame group anxieties, in both real life and in the pages of literature, already was evident in these eras.

As the Chinese government's labor transfer programs have refueled concerns over intermarriage and perceived sexual debasement as threats to collective identity, and as attention to gendered issues has at times dominated Uyghur advocacy

\footnotetext{
${ }^{24}$ See Bellér-Hann (2008, 82-87) for more information on intermarriage in nineteenth- and early twentieth-century Xinjiang.
} 
on the labor programs, the international community's response has been mixed, especially prior to events in June and July 2009 that drew greater attention to the programs. While some U.S. congressional supporters have adopted Uyghur advocacy organizations' description of the programs as the large-scale involuntary transfer of young women (e.g., U.S. Senate Resolution 574), a number of human rights organizations and government offices either have not covered the issue or have done so in cautious terms, largely focusing on labor abuses rather than gender issues (Amnesty International 2006, 2007, 2008, 2009, 2010, 2011; Bureau of Democracy, Human Rights and Labor 2007, 2008, 2009, 2010, 2011; CECC 2007, 2008, 2009, 2010, 2011; Human Rights Watch 2006, 2007, 2008, 2009, 2010, 2011; Office to Monitor and Combat Trafficking in Persons 2006, 2007, 2008, 2009, 2010, 2011). ${ }^{25}$ While limited capacity to independently verify systemic abuses in the labor transfer program may account for some reluctance to adopt the issue in full, the inherent clash between the nationalist anxieties over women's roles and the liberal ideals underpinning the modern human rights movement suggests another source of reticence. If the individuals and institutions that have largely come to define the contours of the contemporary human rights system envision the values of the Universal Declaration of Human Rights realized through tolerance, sexual equality, multicultural exchange, and the free will of each individual, some Uyghur advocacy on the labor transfers appears to present a sharp alternative: a world of insular ethnonationalism where intermarriage is a threat and community mores regarding chastity and marriage may trump the free will of young women.

In the end, it seems little wonder that the labor programs and anxieties about the chastity of women coalesced to form a spark that prompted the protests by Uyghurs in Urumqi on July 5, 2009. At the core of the protests were the perceived injustices stemming from the June 2009 attack at a factory in Shaoguan on transferred Uyghur workers (largely male) by their fellow Han laborers. At the center of that attack was a foggy series of allegations, widely reported, that Uyghur workers raped, sexually assaulted, or acted in an "unfriendly" manner toward a Han woman (CECC 2009, 427n99). Less widely reported-and illustrative of the key role of gender in inflaming group anger, whether Uyghur or Hanwas that some Uyghur accounts of the incident and its causes saw Uyghur women under threat. Some Uyghurs described Uyghur women as the victims in Shaoguan, for example, claiming that Uyghur girls were among factory workers killed by Han during the Shaoguan fight (China Central Television 2009; Facebook n.d.; Millward 2009, 350) or that harassment of Uyghur women factory workers fueled discord between Uyghurs and Han (Radio Free Asia 2009). U.K. Uyghur leader Enver Tohti (2010) concluded: "That Uighur families are being forced to send their daughters away is, I think, the reason why the riots

${ }^{25}$ An employee at the CECC between 2005 and 2012, I was the staff person in charge of writing the Annual Report sections on Xinjiang cited here. 
took place last year," a sentiment later echoed by Rebiya Kadeer (Karlsson 2010). Whether or not diaspora leaders overplayed the role of the transfers for their own political advocacy, the central role of gender in shaping perceptions of and responses to the event are evident. While the July 5 demonstration also reflected outrage at the perceived lax treatment of the Han offenders by Shaoguan police and at the broader mistreatment of Uyghurs, amid a laundry list of political and economic injustices around which Uyghurs might rally, it was perceived injustices bound up with questions of gender, honor, and purity that triggered the initial Uyghur protest.

\section{Conclusion: NuZugum Redux?}

An examination of the story of Nuzugum elucidates how concerns about women's purity and fears of intermarriage have sustained notions of communal identity and animated Uyghur political claims up to the present day. As a mainstay of Uyghur literature renewed and repurposed for new political projects, the story of Nuzugum and the evolution of the narrative trace a trend in Uyghur literary history from the emergence of a new female heroine amid nineteenthcentury innovations in literary form to the adoption of idealized female images to bolster literature in the service of the nation in the twentieth century. The evolution of the story highlights a common thread uniting historical and modern uses of the literary narrative. From its roots as a nineteenth-century oral tale brought into written form in a manner that portrayed collective identity and resistance in eastern Turkistan beyond oasis boundaries, the Nuzugum story subsequently became a vessel for articulating the political aspirations for a unified Uyghur identity (complete with its own literature) in the early twentieth century and a symbol of a fully crystallized nation in later decades. Further examinations of Uyghur literature will broaden our understanding of literature's role in this venture and surely introduce new images of idealized Uyghur women beyond Nuzugum and her literary sisters suffering forced marriage to an outsider. Nuzugum also serves as a reminder of a wider deployment of images of pure women in various cultures, ${ }^{26}$ which, in turn, forms one intersection between gender and constructions of identity as discussed in feminist theory.

Reading the Nuzugum narrative through the lens of feminist theory broadens understandings of Uyghur identity and gender's role in its construction. As Turkic Muslims in eastern Turkistan defined communal boundaries in the late nineteenth century - at the same time oral versions of the Nuzugum tale were being codified in written form-patterns in marriage, procreation, and miscegenation helped stake dividing lines between self and other, Turk and

\footnotetext{
${ }^{26}$ See, e.g., Jager (1996) for an examination of the use of literary and other images of pure women in South Korean pro-unification politics.
} 
non-Turk, and Muslim and non-Muslim. As the spread of nationalist movements gave groups new principles and vocabularies to express their identity, idealized women who remain pure for the nation-epitomized by renewed versions of the Nuzugum narrative-earned their place in an emerging canon of Uyghur national literature and pantheon of national heroes. As current Uyghur political advocacy perpetuates traditions of nationalism even while negotiating new forces affecting Uyghur identity, the perceived threat of intermarriage continues to shape understandings of the collectivity. Gendered analyses elucidate, in particular, the contours of a nationalism that seeks to establish a single vision of history, identity, and boundedness that subsumes individual will in marriage and in labor choices. Examined against existing scholarship that tracks the broad sweep of Uyghur collective identity from pre- or protonationalist senses of belonging to modern notions of the nation, the Nuzugum story and the overlap of its themes with various Uyghur political projects allow for an expanded understanding of Uyghur identity that highlights gender's central position at various junctures in Uyghur history.

Attention to how gender informs current articulations of Uyghur grievances, moreover, underscores the uncertain position of nationalist impulses in the arena of international human rights. Government organizations' and leading human rights organizations' mixed receptivity to Uyghur groups' advocacy on women's involvement in labor transfers highlights enduring tensions between universalism and cultural relativism, "traditional" gender roles versus notions of equality, and the possible limits of a human rights movement that draws on western roots while making claims of global applicability. Examining Uyghur political advocacy inside China, in contrast, challenges assumptions about the homogeneity and aims of Uyghur advocacy and identity, while also spotlighting gender's continued importance in defining notions of the collectivity.

Nuzugum is but one symbol of the significance of gender to Uyghur identity, but a resilient one that has been claimed to stand for the experiences of more than just a single woman. A verse from later versions of the Nuzugum story tells us, "The Tümen River roared and brayed. / In blood, not water, came its cascade. / As witnesses to history, by thousands of Nuzugums / This very poem was made"27 (Hoshur [1983] 2012, 300; Toxtamow 1988, 29).

\section{Acknowledgments}

This paper greatly benefited from the insights and expertise of historian Nabijan Tursun, though viewpoints expressed within are the author's alone. The author also thanks the following people for commenting on the article, sharing sources or helping

\footnotetext{
${ }^{27}$ With minor liberties taken. The original text reads: "The Tümen River roared / Blood flowed in place of water. / As witnesses to history / thousands of Nuzuks wrote [this] poetry." Cited in Hoshur ([1983] 2012, 300) and Toxtamow (1988, 29).
} 
to date them, or providing translations from Russian and Turkish: Abdulcelil Turan, Jim Millward, Gardner Bovingdon, John Osburg, Sean Roberts, Rehmetjan Yusupov, Samuel Bendett, Aziz Isa, Marc Abramson, and three anonymous reviewers.

\section{List of References}

Abdusémetow, Nezerghoja. [1921/1922] 1991. "Nazugum.” In Yoruq Sahillar: Tarixii Matériallar, Shéirlar, Proza [Bright shores: Historical materials, poetry, and prose], comp. Shabdun Ayopow, 204-34. Almaty: Zhazushy.

Abudukelimu, comp., and Jing YA, trans. 1981. Nuozhiguimu [Nuzugum]. Urumqi: Xinjiang renmin chubanshe.

Alptekin, Erkin. 1978. Uygur Türkleri [The Uyghur Turks]. Istanbul: Bo aziçi Yayınları.

Amnesty International. 2002. “2002 Annual Report for Kazakhstan.” http://www.amnestyusa.org/annualreport.php?id=ar\&yr=2002\&c=KAZ (accessed September 30, 2010).

_ 2006. “Amnesty International Report 2006," subsection on “China." http://www. amnesty.org/en/library/asset/POL10/001/2006/en/59ad70c9-d46f-11dd-8743-d305 bea2b2c7/pol100012006en.pdf (accessed July 27, 2012).

—. 2007. "Amnesty International Report 2007," subsections on "Asia Pan Pacific" and "China." http://archive.amnesty.org/report2007/eng/Regions/Asia-Pacific/default. htm and http://archive.amnesty.org/report2007/eng/Regions/Asia-Pacific/China/ default.htm (accessed October 4, 2010).

. 2008. "Amnesty International Report 2008," subsections on "Asia Pacific" and "China." http://archive.amnesty.org/report2008/regions/asia-pacific.html and http://archive.amnesty.org/report2008/eng/regions/asia-pacific/china.html (accessed October 4, 2010).

. 2009. "Amnesty International Report 2009," subsections on "Asia and the Pacific" and "China." http://report2009.amnesty.org/en/regions/asia-pacific and http:// report2009.amnesty.org/en/regions/asia-pacific/china (accessed July 27, 2012).

—. 2010. "Amnesty International Report 2010," subsections on "Asia and the Pacific" and "China." http://report2010.amnesty.org/regions/asia-pacific and http://report 2010.amnesty.org/sites/default/files/AIR2010_AZ_EN.pdf\#page=51 (accessed July 27, 2012).

. 2011. "Annual Report 2011," subsections on “Asia Pacific” and "China." http:// www.amnesty.org/en/annual-report/2011/asia-pacific and http://www.amnesty.org/ en/region/china/report-2011 (accessed June 20, 2012).

Bellér-Hann, Ildikó. 2008. Community Matters in Xinjiang 1880-1949: Toward a Historical Anthropology of the Uyghur. Leiden: Brill.

Benson, Linda K. 1990. The Ili Rebellion: The Moslem Challenge to Chinese Authority in Xinjiang, 1944-1949. Armonk, N.Y.: M.E. Sharpe.

Bilal Nazim (Molla Bilal Binni Molla Yüsüp). [1882] 1909. “Nuzugum.” In Obraztsy taranchinskoi narodnoi literatury sobrannye i perevedennye N.N. Pantusovym [Examples of the literature of the Taranchi people-Collected and translated by N. N. Pantusov], trans. N. N. Pantusov, Proceedings of the Society of Archaeology, History and Ethnography at the Imperial University of Kazan 25:49-60. http:// webappl.dlib.indiana.edu/metsnav/rifias/navigate.do?oid $=$ r254-01\&pn= $25 \&$ size $=$ screen (accessed September 30, 2010). 
—. [1882] 1925. "Nuzugum." In Uyghur el edebyyati [Literature of the Uyghur people], eds. L. Ensary, Z. Beshyr, and I. B. Xudayqol, 224-34. Moscow: S.S.S.R. Xelqlaryng ozek neshryyati.

—_. [1882] 1981. "Nuzugum," ed. Muhemmet Tursun Bahawidin. Bulaq [Water spring] 1:208-25. http://www.uyghurweb.net/Uy/BULAQ81-YIL1-SAN.pdf (accessed September 30, 2010).

Bovingdon, Gardner. 2010. The Uyghurs: Strangers in Their Own Land. New York: Columbia University Press.

Bovingdon, Gardner, with contributions by Nabijan Tursun. 2004. "Contested Histories.” In Xinjiang: China’s Muslim Borderland, ed. S. Frederick Starr, 353-74. Armonk, N.Y.: M.E. Sharpe.

Brophy, David. 2005a. “Taranchis, Kashgaris, and the 'Uyghur Question' in Soviet Central Asia." Inner Asia 7(2):163-84.

—. 2005b. "Forced Marriages and Female Heroines in Uyghur Culture." Harvard Asia Quarterly 9(1/2):57-65.

—. 2011. "Tending to Unite? The Origins of Uyghur Nationalism." PhD diss., Harvard University.

Bureau of Democracy, Human Rights, and Labor, U.S. Department of State. 2007. "Country Report on Human Rights Practices—2006, China (includes Tibet, Hong Kong and Macau).” March 6. http://www.state.gov/g/drl/rls/hrrpt/2006/78771.htm (accessed October 1, 2010).

—. 2008. "Country Report on Human Rights Practices—2007, China (includes Tibet, Hong Kong and Macau).” March 11. http://www.state.gov/g/drl/rls/hrrpt/2007/ 100518.htm (accessed October 1, 2010).

—. 2009. "Country Report on Human Rights Practices—2008, China (includes Tibet, Hong Kong and Macau).” February 25. http://www.state.gov/g/drl/rls/hrrpt/2008/ eap/119037.htm (accessed October 1, 2010).

—. 2010. "Country Report on Human Rights Practices—2009, China (includes Tibet, Hong Kong and Macau).” March 11. http://www.state.gov/j/drl/rls/hrrpt/2009/eap/ 135989.htm (accessed June 20, 2012).

—. 2011. "Country Report on Human Rights Practices—2010, China (includes Tibet, Hong Kong and Macau).” April 8. http://www.state.gov/j/drl/rls/hrrpt/2010/eap/ 154382.htm (accessed June 20, 2012).

Caprioni, Elena. 2008. "A Look inside the Heterogeneous World of Women in Northwestern China.” International Journal of Interdisciplinary Social Sciences 3(2): 149-60.

Cha, Ariana Eunjung. 2009. "China Unrest Tied to Labor Program." Washington Post, July 15. http://www.washingtonpost.com/wp-dyn/content/article/2009/07/14/ AR2009071403321_pf.html (accessed October 1, 2010).

China Central Television. 2009. “7 $7-5$ ” shijian shimo” [Full story of “7-5” incident]. October 15. http:/news.cctv.com/china/20091015/104748.shtml (accessed July 24, 2012).

Congressional-Executive Commission on China (CECC). 2007. “2007 Annual Report.” October 10.

—. 2008. "2008 Annual Report.” October 31.

- 2009. "2009 Annual Report.” October 10.

—. 2010. "2010 Annual Report.” October 10.

—. 2011. "2011 Annual Report.” October 10.

Dautcher, Jay. 2009. Down a Narrow Road: Identity and Masculinity in a Uyghur Community in Xinjiang China. Cambridge, Mass.: Harvard University Asia Center. 
Eli, Ayxem. 2006. "Gender, Social Hierarchy and Ethnicity-A Case Study of Urban Kashgar, XUAR, China.” PhD diss., University of Melbourne.

Fасевоок. n.d. Untitled posting under topic titled “Ana til yéziqining köz yéshi." http:// www.facebook.com/topic.php?uid=91819762333\&topic $=9051$ (accessed October 3, 2010).

Gladney, Dru C. 1990. “The Ethnogenesis of the Uighur.” Central Asian Survey 9(1): $1-28$.

Hemraéw, M., B. Ershidinow, and I. Imirow. 1993. Uyghur edebiyati [Uyghur literature]. Almuta: Rayan.

Hoshur, Memtimin. [1983] 2012. “Nozugum.” In Tolun Ay: Memtimin hoshur eserliridin tallanma [Full moon: Selected works from Memtimin Hoshur], vol. 1, 2nd ed., 30073. Urumqi: Shinjang yashlar-ösmürler neshriyati.

—. 2006. Ili xelq naxshilirining tarixiy bayani [Historical account of Ili folk songs]. Beijing: Milletler neshriyati.

Human Rights Watch. 2006. "World Report 2006_China." January 18. http://www.hrw. org/english/docs/2006/01/18/china12270.htm (accessed September 30, 2010).

—. 2007. "World Report 2007_China." January 11. http://www.hrw.org/englishwr2k7/ docs/2007/01/11/chinal4867.htm (accessed September 30, 2010).

—. 2008. "World Report 2008—China." January 31. http://www.hrw.org/worldreport-2008/china (accessed September 30, 2010).

—. 2009. "World Report 2009_China." January 14. http://www.hrw.org/en/node/ 79301 (accessed September 30, 2010).

—. 2010. "World Report 2010—China." January 20. http://www.hrw.org/en/node/ 87491 (accessed September 30, 2010).

—. 2011. "World Report 2011-China." January 24. http://www.hrw.org/ world-report-2011/china (accessed June 20, 2012).

Jacobs, Andrew. 2009. “At a Factory, the Spark for China’s Violence.” New York Times, July 15. http://www.nytimes.com/2009/07/16/world/asia/16china.html (accessed October 1, 2010).

Jager, Sheila Miyoshi. 1996. "Women, Resistance and the Divided Nation: The Romantic Rhetoric of Korean Reunification.” Journal of Asian Studies 55(1):3-21.

Janhunen, Juha. 1996. Manchuria: An Ethnic History. Helsinki: Finno-Ugrian Society.

Karlsson, IDA. 2010. “China: On the Thousand Mothers March.” Inter Press Service, October 20. http://www.ipsnews.net/news.asp?idnews=53223 (accessed December 31, 2010).

Kazakhstan SSR Academy of Sciences, Linguistics Institute, Uyghur Studies DivISION. 1983. Uyghur edebiyatining qisqiche tarixi [A short history of Uyghur literature]. Almuta: Kazakhstan SSR Nauka.

Kim, Hodong. 2004. Holy War in China: The Muslim Rebellion and State in Chinese Central Asia, 1864-1877. Stanford, Calif.: Stanford University Press.

Kuzhamiarov, Kuddus. 1958. "Tantsy iz opery 'Nazugum”" [Dances from the opera "Nazugum"]. Moscow: Sowemskii Kompozimor.

Li Yongfeng. 2009. "Zhuanfang: weizu NGO gongzuozhe, qian xinjiang fazhibao zongbianshi zhuren hailaite" [Special report: Uyghur NGO worker and former Xinjiang Legal Daily editorial office director Gheyret]. Asia Weekly, August 2. http://www. yzzk.com/cfm/Content_Archive.cfm?Channel=ag\&Path=2311577102/30ag3a.cfm (accessed September 30, 2010).

Light, Nathan. 1998. "Slippery Paths: The Performance and Canonization of Turkic Literature and Uyghur Muqam Song in Islam and Modernity.” PhD diss., Indiana University. 
Mayer, Tamar. 2000. "Gender Ironies of Nationalism: Setting the Stage." In Gender Ironies of Nationalism: Sexing the Nation, ed. Tamar Mayer, 1-22. London: Routledge.

McLaughlin, Kathleen E. 2009. “At a Nike Factory, Uighur Workers Worry.” Global Post, July 13. http://www.globalpost.com/dispatch/china-and-its-neighbors/090713/ uighur-workers-guangdong (accessed October 1, 2010).

Meshrep. 2006. "Uyghur qizi nuzugum” [Uyghur girl Nuzugum]. December 16. http:// www. meshrep.com/wforum/viewtopic.php? $\mathrm{p}=44436 \&$ sid $=55 \mathrm{a} 2 \mathrm{~b} 39 \mathrm{c} 08 \mathrm{~d} 4 \mathrm{a}-$ c471022a56d349cee92 (accessed October 1, 2010).

Millward, James A. 1994. "A Uyghur Muslim in Qianlong's Court: The Meaning of the Fragrant Concubine." Journal of Asian Studies 53(2):427-58.

—. 2007. Eurasian Crossroads: A History of Xinjiang. New York: Columbia University Press.

—. 2009. "Introduction: Does the 2009 Urumchi Violence Mark a Turning Point?" Central Asian Survey 28(4):347-60.

Mollawutow, Sawut. [1968] 2002. "Uyghur xelqining uluq shairi" [The great poet of the Uyghur people]. In Uyghur edebiyati dawamliri [Continuations of Uyghur literature], Sawut Mollawutow, 102-5. Almuta: Self-published.

"Nazugum." 2008. Posted on YouTube under the title "Nozugum." August 23. http:// www.youtube.com/watch?v=_IZgifWVcXQ (accessed October 1, 2010).

Newby, Laura J. 2007. "Us and Them' in Eighteenth and Nineteenth Century Xinjiang." In Situating the Uyghurs Between China and Central Asia, eds. Ildikó Bellér-Hann, M. Cristina Cesàro, Rachel Harris, and Joanne Smith Finley, 15-29. Hampshire, UK: Ashgate.

"Nuzugum." n.d. Advertisement posted on Sina. http://video.sina.com.cn/v/b/ 21672729-1620461191.html\#38932500 (accessed October 1, 2010).

Office to Monitor and Combat Trafficking in Persons, U.S. Department of State. 2006. "Trafficking in Persons Report 2006-China." June 5. http://www.state.gov/ g/tip/rls/tiprpt/2006/65988.htm (accessed October 1, 2010).

—. 2007. "Trafficking in Persons Report 2007-China." June 12. http://www.state.gov/ g/tip/rls/tiprpt/2007/82805.htm (accessed October 1, 2010).

—. 2008. "Trafficking in Persons Report 2008 —China." June 4. http://www.state.gov/g/ tip/rls/tiprpt/2008/105387.htm (accessed October 1, 2010).

—. 2009. “Trafficking in Persons Report 2009_China.” June 16. http://www.state.gov/ g/tip/rls/tiprpt/2009/123135.htm (accessed October 1, 2010).

— . 2010. "Trafficking in Persons Report 2010—China." June 14. http://www.state.gov/ g/tip/rls/tiprpt/2010/142759.htm (accessed October 1, 2010).

— . 2011. "Trafficking in Persons Report 2011—China." June 27. http://www.state.gov/ j/tip/rls/tiprpt/2011/164231.htm (accessed June 20, 2012).

Ömer, Uchqunjan, 1981. Uyghur xelq tarixi qoshaqliri [Historical folk songs of the Uyghur people]. Kashgar: Qeshqer uyghur neshriyati.

Pantusov, Nikolai. N. 1890. Taranchinskiia piesni. Sobrany I perevedny [Taranchi songs. Collected and translated]. St. Petersburg: Tip. I. Akademii nauk.

Perdue, Peter C. 2005. China Marches West: The Qing Conquest of Central Eurasia. Cambridge, Mass.: Belknap Press of Harvard University Press.

Radio Free Asia. 2008. “Amérika uyghurliri noruzni kütüwaldi [American Uyghurs welcomed Noruz]. March 23. http://www.rfa.org/uyghur/xewerler/uyghur/noruz-gheyt20080323.html/story_main?encoding=latin (accessed October 1, 2010).

—. 2009. “"No Rapes’ in Riot Town.” June 29. http://www.rfa.org/english/news/uyghur/ ethnic-clash-06292009102144.html (accessed July 23, 2012). 
Radio Free Asia Unplugged. 2010. “Top Uyghur Activist Asks State Department to Do More for Human Rights.” March 16. http://www.rfaunplugged.org/2010/03/16/ top-uyghur-activist-asks-state-department-to-do-more-for-human-rights/ (accessed December 29, 2010).

Radloff, Wilhelm. 1886. Proben der Volkslitteratur der nördlichen türkischen Stämme, Vol. 6.1, Dialect der Taranschi [Investigations of the folk literature of the northern Turkish tribes, vol. 6.1, Dialect of the Taranchi]. St. Petersburg: Tipografiya Imperatorskoi Akademii Nauk.

Rafto Foundation for Human Rights. 2010. "Rebiya Kadeer-Five Years of Freedom." September 2. http://www.rafto.no/?page=55\&news=193 (accessed March 28, 2012).

Ranchod-Nilsson, Sita, and Mary Ann Tétreault. 2000. "Gender and Nationalism: Moving Beyond Fragmented Conversations." In Women, States, and Nationalism: At Home in the Nation?, eds. Sita Ranchod-Nilsson and Mary Ann Tétreault, 1-17. London: Routledge.

Reuters. 2007. "Uighur Activist Asks U.S. to Help Stop China Removals.” October 31. http://www.reuters.com/article/idUSN3136946020071101 (accessed October 1, 2010).

Roberts, Sean R. 2003. "Uyghur Neighborhoods and Nationalisms in the Former SinoSoviet Borderland: An Historical Ethnography of a Stateless Nation on the Margins of Modernity." PhD diss., University of Southern California.

. 2009. "Imagining Uyghuristan: Re-evaluating the Birth of the Modern Uyghur Nation." Central Asian Survey 28(4):361-81.

Rudelson, Justin Jon. 1997. Oasis Identities: Uyghur Nationalism Along China's Silk Road. New York: Columbia University Press.

TASH, HüsIYIn. 2003. Ayallarning iptixari-nuzugum [Women's pride-Nuzugum]. Urumqi: Shinjang xelq neshriyati.

Tilivaldi, Alimzhan. 2005. Zolodaya dolina: $k$ 70-let obraz [Golden valley: 70 years of images]. Almaty: Publisher unknown.

Tohti, Enver. 2010. Remarks delivered at Quilliam Roundtable on "The Uyghurs: China’s Forgotten Muslims.” April 12. http://www.quilliamfoundation.org/index. php/component/content/article/652 (accessed October 1, 2010).

“Tom Lantos Commission on Human Rights Hears Testimony on China's One Child Policy." 2009. Reprinted on Uyghur American Association Web site. November 11. http://www.uyghuramerican.org/articles/3982/1/Tom-Lantos-Commission-onHuman-Rights-Hears-Testimony-on-Chinas-One-Child-Policy/index.html (accessed October 4, 2010).

Toxtamow, Turghan (Turghan Toxtemow, Turghan Toxmenow). 1988. Nazugum. Almuta: Zhazushy.

—. (Turghan Toxtem). 2001. Nuzugum. Urumqi: Shinjang yashlar-ösmürler neshriyati.

United States Senate Resolution 574 (introduced). 2008. 110th Congress. May 22. http://homas.loc.gov/cgi-bin/query/z?c110:S.RES.574: (accessed July 25, 2012).

Uyghurbiz. 2009. "Uyghur meshhur shexsliri" [Famous Uyghur individuals]. March 20. http://uighurbiz.net/forum/viewthread.php?action=printable\&tid=1390 (accessed October 1, 2010).

"Uyghur Farmers: Forced Labor, Forced Migration of Girls." 2008. Posted on YouTube. April 19. http://www.youtube.com/watch?v=yX8HvrmzVvg (accessed October 1, 2010).

Uyghur Human Rights Project (UHRP). 2007. "Rebiya Kadeer Addresses PRC Trafficking of Uyghur Women and Girls at Congressional Briefing." November 1. http://www. 
uhrp.org/articles/556/1/Rebiya-Kadeer-addresses-PRC-trafficking-of-Uyghur-womenand-girls-at-Congressional-briefing-/index.html (accessed October 1, 2010).

. 2008. "Deception, Pressure, and Threats: The Transfer of Young Uyghur Women to Eastern China.” February 8. http://docs.uyghuramerican.org/Transfer_uyghur_ woman.pdf (accessed October 1, 2010).

Wetinim. 2009. "Uyghur tarixida ötken meshhur ayal edibler" [Famous women literary figures in Uyghur history]. May 6. http://www.wetinim.org/forum/viewthread.php? tid=964\&extra $=$ page\%3D1\&sid=zG63GU (accessed October 1, 2010).

Yasin, Nurmemet. 2004. "Nuzugumning chaqiriqi" [The call of Nuzugum], Tengritagh Literature, October 12 (conjectured date and publisher). Reprinted on the London Uyghur Ensemble Web site, trans. Aziz Isa and Rachel Harris. http:// www.uyghurensemble.co.uk/en-html/poems4.html (accessed October 1, 2010).

Yuval-Davis, Nira. 1997. Gender and Nation. London: SAGE.

Yuval-Davis, Nira, and Floya Anthias. 1989. "Introduction.” In Woman-Nation-State, eds. Nira Yuval-Davis and Floya Anthias, 1-15. New York: St. Martin’s Press. 